\title{
DÁNÉ VERONKA*
}

\section{LIBER BARONATUS A FEJEDELEMSÉGKORI ERDÉLYBEN $(1541-1658)^{-\prime \prime}$}

\author{
Kulcsszavak: liber baronatus, jogtörténet, Erdélyi Fejedelemség
}

Bizonyára minden kutató számára jól ismert az a helyzet és érzés, amikor egy kérdéssel másmás szálon futó vizsgálódásai során újra és újra szembesül (ha úgy tetszik, minduntalan eléje tolakodik), s bár esetleg valamilyen mértékben, vonatkozásban sikerül tisztáznia, továbbra is ott mocorog az elégedetlenség, hiányérzet, hogy az általa adott válasz nem kellóképpen világos, és a kérdéskör mögött - a rendelkezésre álló adatok alapján - többet gyanít. Az erdélyi liber baronatusszal, pontosabban annak tényleges múködésével, egy évtizede, a Bocskaiak görgényi-vécsi szabad urasága, Bocskai Miklósnak emiatt Torda vármegye nemesi universitasával kialakult ellentéte kapcsán foglalkoztam először, elsősorban jogtörténeti szempontból és elsősorban erre az adott esetre összpontosítva. ${ }^{1} \mathrm{Az}$ azóta eltelt esztendőkben nyilvánvalóvá vált, hogy ez csupán pillanatfelvételnek tekinthető, és több fontos kérdésre csak akkor adható - remélhetôleg kimerítőbb - válasz, ha egyrészt az eddigi kutatás pillanatképeit, azaz minden egyes ismert esetet sorozatba rendezve mozgóképpé alakítjuk, másrészt sokkal szélesebb kontextusba, a korszak történéseinek folyamatába helyezve vizsgáljuk.

Magával az „intézménnyel” a 19. század utolsó évtizedeitől kezdődően foglalkozott a kutatás, időról időre felbukkant a szakirodalomban. Mindmáig e tekintetben Schiller Bódognak a fő́rendiség kialakulásáról írott munkája a leggyakrabban hivatkozott, ${ }^{2}$ annak ellenére, hogy a középkor vonatkozásában Engel Pál már két évtizede figyelmeztetett az általa alkalmazott módszer elhibázott voltára, és ebből következően megállapításai túlhaladottságára. ${ }^{3}$ Ami a kora újkori erdélyi liber baronatust illeti, kétségtelen, hogy szintén elsősorban Schillerhez vezethetô vissza több olyan megállapítás, amely hosszú ideig a tisztánlátást akadályozta. Vitathatatlan, hogy egyes elemeket, tényeket helyesen ismert fel és értékelt ('igy például a megyei igazságszolgáltatás alóli mentességet és az adott területen teljes bíráskodási jogható-

* DÁné Veronka (1974), PhD, történész, a Debreceni Egyetem Középkori, Koraújkori Magyar Történeti és Segédtudományi Tanszékének egyetemi adjunktusa, Debrecen. E-mail: dane.veronka@ arts.unideb.hu.

** A tanulmány az OTKA K 112291 pályázat keretében készült.

1 DÁNÉ Veronka: A Bocskaiak Erdélyben - Törvénytelen liber bárók? = „Frigy és békesség legyen ...” $A$ bécsi és a zsitvatoroki béke. Szerk. PAPp Klára-JEneY-Tóth Annamária. Debreceni Egyetem Történelmi Intézete, Debrecen, 2006 (A Bocskai-szabadságharc 400. évfordulója VIII). 111-118.

2 Schiller Bódog: Az örökös förendiség eredete Magyarországon. Kilián Frigyes utóda, Bp., 1900.262287, különösen: 280-282. (63. jegyz.)

3 Engel Pál: Néhány XIV. századi erdélyi alvajda származása = Emlékkönyv Jakó Zsigmond születésének nyolcvanadik évfordulójára. Szerk. Kovács András-Sipos Gábor-Tonk Sándor. EME, Kvár, 1996. 176. 
ságot, amelyben, véleménye szerint, az erdélyi liber baronatus fogalma ki is merült). ${ }^{4}$ Azonban az erdélyi fejlődés tekintetében is ugyanazon általános igazságok, általános szabályok megállapításának elve, vágya vezette zsákutcába, mint a Mohács előtti időszak esetében. Az általánosítás ugyanis óhatatlanul „összemosáshoz” vezetett, fogalmi szinten mindenekelőtt, így a „német birodalmi bárókkal”, ${ }^{5}$ liber comitatusszal, az örökös grófsággal/ispánsággal. ${ }^{6}$ Utóbbival azonban csak bizonyos esetekben tekinthető azonosnak, pontosabban bizonyos esetekben az örökös ispánságot/grófságot szabad urasággal együtt nyerték el, gyakorolták. Jelzésértékü, hogy magával az örökös ispánsággal nem voltak gondjai az erdélyi rendeknek, azaz nem tiltakoznak ellene, legalábbis eddig egyetlen eset sem ismert. Hasonlóképpen zavart okozott Schiller a bizonyos mértékben a mágnássá, báróvá emeléssel való megfeleltetéssel, ezek beemelésével a liber baronatus tárgyalásába. Koncepciója miatt ugyanakkor sem a liber baronatusi címmel, kiváltságokkal felruházott személyekre, sem az általuk ilyen jogon birtokolt uradalmakra, ezek történetére, jellegére nem fordított alaposabb figyelmet, nem különítette el (ahogyan a kutatás a későbbiek folyamán sem) az uralkodó, illetve kincstár, valamint az egyház (természetesnek tekinthető) immunitását, szabad uraságát és a magánszemélyek által gyakoroltat. Az eddigiek után nem meglepő, hogy a liber barók megjelenésének korszakára sem figyelt fel, vagy hogy a kétségkívül nagyrészt azonos alapokról induló, de ekkor már nyilvánvalóan külön utas erdélyi fejlődést a királyságbelivel kívánta azonosítani, meglehetősen vitatható, bizonytalan és erőltetett fogalmi megfeleltetések árán is. ${ }^{7}$

Schillert követően a 20. században a kérdéssel a gyalui váruradalom kapcsán Jakó Zsigmond foglalkozott, Sennyei Pongrác itteni liber baronatusságát tárva fel. ${ }^{8}$ Igaz, hogy csupán erre az egy esetre és summásan tért ki, ugyanebben az évben egy másik tanulmányában viszont egy korábban figyelmen kívül hagyott tényre hívta fel a figyelmet: liber barói jogokkal együtt birtokolt (vár)uradalmakkal - egy, könnyen magyarázható, érthető kivétellel - az ország stratégiai fontosságú pontjain nem találkozunk. ${ }^{9}$ Majdnem három évtizeddel később a Kővár vidéki társadalomról írott munkájában Szentgyörgyi Mária próbálta meg definiálni a fogalmat, részleges sikerrel, eleve hibás kiindulópontból, ugyanis az általa említett időpontban Kővár már több évtizede az ország egyik végvára, kincstári birtok volt, más törvényhatóság alóli mentessége természetes. ${ }^{10} \mathrm{~A}$ kérdést a múlt században utoljára a vármegyei filiális szék és ennek kapcsán az erdélyi úriszék fejlődését vizsgálva Kiss András tűzte napirendre. ${ }^{11} \mathrm{Az}$ eddig elmondottak jól szemléltetik a mozaikosságot, részleges eredményeket, ilyennek tekintem a már említett tanulmányomat is. A következőkben a Schiller-féle nézőpontot megfor-

\footnotetext{
4 SCHILler: i. $m .280$.

5 Uo.

6 Uo. 281-282.

7 Uo. 281.

8 A gyalui vártartomány urbáriumai. Bevezetéssel ellátva közzéteszi Jakó Zsigmond. Erdélyi Tudományos Intézet, Kvár, 1944. XVI.

9 JAKó Zsigmond: Belsö-Szolnok és Doboka magyarsága az üjkorban = Szolnok-Doboka magyarsága. Szerk. Szabó T. Attila. Dés-Kvár, 1944. 82.

10 Szentgyörgyi Mária: Kövár vidékének társadalma. Akadémiai, Bp., 1972 (Értekezések a történeti tudományok köréből 56). 27, 30-33.

11 KIss András: $A$ vármegyei filiális szék keletkezéséröl = Uő: Források és értelmezések. Kriterion, Buk., 1994. 39-69, különösen 55-62.
} 
dítva, a hiányolt szempontok beemelésével, az egyeditől (az egyes pillanatfelvételtől) az esetleges, korántsem törvényszerű általános felé haladva kísérlem meg a liber baronatus erdélyi fejlődésének, működésének bemutatását.

Természetesen a szabad uraságot az uralkodó adományából lehetett elnyerni. Az ismert ilyen jellegű adományleveleknél azonban jóval több szabad uraságról tudunk, ez pedig csak részben magyarázható a források pusztulásával. Ráadásul az ilyen jogú területek számbavételekor egy igen érdekes jelenségre, tényre figyelhetünk fel, ezért úgy vélem, mindenekelőtt a szabad uraságok inventáriumát kell összeállíani. A szakirodalom a liber baronatusságok felsorolásának rendjén kiindulópontként vagy kizárólag az 1607.júniusi (esetleg a későbbi, 1630., 1635., 1639.) országgyúlési artikulust ${ }^{12}$ használja, illetve néhány olyat, amelyekre vonatkozóan nemes egyszerűséggel elhallgatják forrásaikat, következésképpen mindaddig, míg/ha ezek előkerülnek, nem vehetjük számításba. (Ez a helyzet a Schiller felsorolásában szereplő Torockó és Hunyad esetében. ${ }^{13}$ Utóbbi feltételezhetően az enyingi Törökök örökös ispánsága miatt kerülhetett Schiller felsorolásába). Az említett 1607-es törvénycikk azonban önmagában biztos alapnak sem használható, mivel, mint az alábbiakból kiderül, maguknak a területeknek a vonatkozásában sem teljes. Másodsorban pedig az artikulusok normatív jellegükből fakadóan természetesen nem adnak választ arra a kérdésre, hogy az illető terület (uradalom, tartomány) mióta liber baronatus? (A korszak, időpont kérdésére a későbbiekben még visszatérek, mivel véleményem szerint nagyon fontos a téma szempontjából.) Ráadásul gyakran a birtokos személye, annak státusa is rejtve maradt. (E tekintetben az utóbbi években folyó birtokos társadalomra vonatkozó kutatások, illetve a vármegyei jegyzőkönyvek hoztak értékes adatokat.)

Időrendben haladva I. Ferdinánd 1541. februári adománylevelében bukkan fel a „liber dominus et comes perpetuus castri/terrae Fogaras” cím Nádasdy Tamás, Mayláth István, Szalay János fogarasi birtoklása kapcsán. Werner György és Bornemisza Pál püspök, Ferdinánd biztosai 1552/53-ban ugyancsak Fogarasról jelentették ki, hogy „Mayláth Istváné volt, de most somlyai Báthory Andrásé, a várhoz nagy uradalom és földterület tartozik, amely mentes a contributiótól és más terhektől, és emiatt minden más magyarországi és erdélyi várnál jelesebb, és mindig királyi tulajdonban szokott lenni”. ${ }^{14}$ (Ugyancsak királyi birtokként sorolják fel Almás, Léta, Küküllő, Déva és Görgény várát, uradalmait. ${ }^{15}$ ) Ugyanezt az állapotot tanúsítja az 1558. szeptemberi gyulafehérvári országgyúlés artikulusa. A rendek azon panaszára ugyanis, hogy Fogaras és birtokosa nem viseli a közterheket, becikkelyezték, hogy a királyné kényszerítse a többi országlakóval egyenlő hozzájárulásra. ${ }^{16}$ Ugyanekkor a moldvai vajda által (akárcsak a Mohácsot megelőző korszakban) a király kegyelméből birtokolt küküllővári

12 Erdélyi országgyúlési emlékek. 1540-1699. I-XXI. Szerk. Szilágyi Sándor. MTA, Bp., 18751898. (a továbbiakban EOE) 1607: V. 501-502.; 1630: IX. 86.; 1635: IX. 432, 1639: X. 222.

13 SCHILleR: i.m. 280.

14 Кӧzli Ововлі Teréz: Erdély pénzügyei I. Ferdinánd uralma alatt 1552-1556. Szentpétery Imre Történettudományi Alapítvány, Bp., 2002 (Fons könyvek 1). 108.

15 Uo. 108-109.

16 „quod cum districtus terrae Fogaras in hoc regno existat, curaque impensis et defensione Maiestatum suarum sacrarum et fidelium regnicolarum suorum defendantur et conseruentur, cum eisdem regnicolis aequalia onera sentire, supportareque debeant, ad quod praestandum ut Maiestates suae Sacrae possessorem eiusdem terrae Fogaras cogere dignetur [...].” EOE II. 106. 
váruradalom hasonló immunitását és népeinek erdélyi törvényeken kívüliségét kifogásolták és szüntették meg a rendek. ${ }^{17}$ 1573-ban viszont Miksa Bekes Gáspár János Zsigmondtól nyert fogarasföldi örökös ispánságát (implicite liber baronatusát) erősítette meg, egyben a királyi joggal is megadományozva. ${ }^{18}$ Közismert, hogy Miksa és Báthory István viszonya ekkortájt már meglehetősen feszültté vált, ahogyan az utóbbi és Bekes közti is. (Megjegyzésre érdemes, hogy 1585. május 12-i végrendeletében Báthory István éppen Fogaras adó- és teherviselés alóli mentessége miatt rendelkezett úgy, hogy ennek ellensúlyozására mindenkori tulajdonosa kétszáz lovast és 100 gyalogost - jó katonákat, nem bojárokat - köteles kiállítani általános hadfelkelés esetén. ${ }^{19}$ )

Ezt követően csaknem húsz esztendeig a források - egyelőre - nem említik a szabad uraságot, hogy aztán majd két évtizedig, ha nem is folyamatosan, de a korábbiakhoz viszonyítva szinte „dúskáljunk” az adatokban. 1591-ben Alfonzo Carillo atya egyik levelében a katolicizmus pozícióinak visszahódítása kapcsán megemlíti, hogy erre komoly reményük lehet például Fogaras vidékén, amelynek teljhatalmú birtokosa Báthory Boldizsár, és ott azt tesz, amit akar. ${ }^{20}$ Fogarast Bethlen Farkas szintén Báthory Boldizsár baronatusának mondja. ${ }^{21} 1598$ októberében Szuhay püspök és Istvánffy Miklós, Rudolf erdélyi biztosai az országlakosok és a kincstár számára igen káros praerogativa vagy még inkább abusus megszüntetését kérték az uralkodótól, tudniillik Bocskai István görgényi és Náprágyi Demeter püspök, kancellár gyalui liber baronatusságát, mivel ezek „nullae in publicum contributiones, nulla subsidia, nulli milites, nulla annona, nihil auxilii confertur”. ${ }^{22} 1599$ márciusában hasonló kérést fogalmaztak meg a rendek a visszatért és éppen újra lemondani készülő Zsigmondhoz. ${ }^{23}$ (Vélhetően ez volt az a kérelem, amelyre majd az 1607-es artikulusban utaltak a rendek.) Azontúl, hogy a biztosok adó-, hadügyi vonatkozásban meglehetősen pontos meghatározását adják a szabad uraságnak, a jelentésük érdekessége, hogy az 1599-es cikkely szövegétől eltérően Náprágyinak nem püspökként, hanem kancellárként való birtoklásáról beszél. Ưjabb szinte évtizednyi szünet után a már említett, 1607-es artikulus mondta ki megszüntetését, Görgényt, Vécset és

17 „bona spectabilis ac magnifici domini Vayuodae Moldauiensis, per Maiestates suas sacras dominationi suae magnificae concessa, eiusdemque servitores ita in hoc regno habere, et conseruari facere, ut aequalia onera publica contributionis et emergentium necessitatum, iuriumque processus subire tollerareque debeant, et pro factis eorum contra comites de remedio opportuno animaduertere, ne de cetero similia facinora perpetranda attentare audeant." Uo.

18 „János Zsigmond Fogaras földjét szabad báróságként adta neki, és azt állította, hogy ő senki hatalmának nincs alávetve”. BEThlen Farkas: Erdély története. III. (1571-1594). Ford. Bodor András. Enciklopédia-EME, Bp.-Kvár., 2004. 20; Magyar Nemzeti Levéltár Országos Levéltára, Magyar Kancelláriai Levéltár, A 57. Magyar Királyi Könyvek, III. kötet. 1055-1056. (http://mnl. gov.hu/adatbazisok)

19 Báthory Istuán erdélyi fejedelem és lengyel király levelezése. II. 1576-1586. Közrebocsátja Veress Endre. Erdélyi Tudományos Intézet, Kvár, 1944. 299-300.

20 Monumenta Antiquae Hungariae III. (1587-1592) Ed. Ladislaus Lukács S. I. Romae, 1969. 615,630 .

21 Wolffgangus Bethlen: Historia de rebus Transsylvanicis. Tom. III. Cibinii, 1783. 489; BethLEN Farkas: Erdély története IV. (1594-1597). Ford. Kasza Péter-S. VArga Katalin. EnciklopédiaEME, Bp.-Kvár, 2006. 90.

22 EOE IV. 214-215.

23 EOE IV. 276. A kiadó figyelmét az 1598-as kérelem említése nyilván elkerülte, ezért nyilvánította hibásnak a „kívántuk” változatot. Lásd Uo. 2. jegyz. 
Dévát nevezve meg. A következő év májusában Torda vármegye nemesi universitasa sérelmezte, hogy Bocskai Miklós görgényi és vécsi uradalmaiban „szabados úrként” jár el. ${ }^{24}$ Fellépésüknek meg is lett az „eredménye”: szeptemberben Báthory Gábor a görgényi váruradalmat 36 ezer aranyforintban, a vécsit pedig 60 ezer magyar forintban inskribálta és megerősítette ezen jogaiban, ${ }^{25} 1609$ május 20-án pedig ugyanezekkel ruházta fel Sennyei Pongrácot gyalui (és minden más, országbeli) uradalmában. ${ }^{26}$ A Sennyei esete után már a meglepetés erejével sem hat, hogy az 1609. októberi (amely Homonnai Bálint birtokainak, feltehetően kővári uradalmának, adózás alóli immunitását is említi) országgyưlés tiltása ${ }^{27}$ ellenére, a diéta után alig néhány héttel liber baronatusi jogokat adományozott Kornis Boldizsárnak is. ${ }^{28}$ (Az azonban említésre méltó, hogy a Királyi Könyvekben egyik privilégiumnak sem találjuk nyomát, holott Sennyei adományának napján három, Kornisén pedig egy feljegyzés bevezetésre került.) Az 1609-es, illetve az 1610. márciusi diéta tiltásait ${ }^{29} 1614$ februárjában (szintén az adózással kapcsolatosan), ${ }^{30}$ majd 1620-ban megújították, ${ }^{31}$ immár a területek megnevezése nélkül, hatálya alól Fogarast emelve ki. Az 1658-ig terjedő évtizedekben Újtorda (az idetelepített katonaelemek vármegyétől való independentiája, 1628), ${ }^{32}$ Szunyogh Gáspár kövesdi jószága (gonosztevők üldözésének „kisajátítása”, 1631), ${ }^{33}$ Kun László máramarosi birtokai (a cirkálóknak birtokaira való be nem bocsátása, 1633), ${ }^{34}$ Zaránd és Szörény megyebeli valamiféle liber baronatusság (1635), ${ }^{35}$ a Bihar vármegyei hajdúk (1634), ${ }^{36}$ Jósika Gábor Szörény vármegyétől való independentiája $(1639)^{37}$ és megnevezetlen máramarosi birtokosok $(1650)^{38}$ kerültek az

24 Torda vármegye jegyzókönyvei I. 1607-1658. Bevezető tanulmánnyal és jegyzetekkel közzéteszi DÁné Veronka. EME, Kvár, 2009 (Erdélyi Történelmi Adatok IX. 1). 51.

25 Erdélyi fejedelmek oklevelei (1560-1689) - Erdélyi Királyi Könyvek DVD. Szerk. Gyulai Éva. Bp. 2004. VIII. 70-72. A görgényi uradalmat ekkor 11 egész- és 11 részbirtok, a vécsit hat teljes, nyolc részbirtok és hat praedium alkotta.

26 Erdélyi Nemzeti Múzeum Levéltára (a Román Nemzeti Levéltárak Kolozs Megyei Fiókja [Serviciul Judeţean Cluj al Arhivelor Naţionale ale României] kezelésében), kissennyei Sennyei család levéltára (Fond familial Sennyei), Fasc. Privilegiorum nr. 7.

27 EOE VI. 166. (15., 18. art.)

28 T. Orgona Angelika: A göncruszkai Kornisok. Két generáció túlélési stratégiai az erdélyi elitben (1546 k. -1646). PhD disszertáció, 2007. 129. (Online: http://doktori.btk.elte.hu/hist/orgona/ disszert.pdf) Az adománylevél kelte: 1609. okt. 26.

29 Uo. 175-176.

30 Uo. 420.

31 EOE VII. 543.

32 EOE VIII. 485.

33 „Mivel kegyelmes urunk Szúnyogh Gáspár az kövesdi jószágra oly privilegiumot extrahált volt, hogy az malefactorok büntetése, kergetése, csak ő rajta álljon, végeztük, hogy ott sem lehet liber baronatusság; ezért observáltassék ott is az régi usus.” EOE IX. 269.

34 „Kún László uramnak is az mennyi jószága Máramarosban vagyon, concludáltuk, hogy az vármegye ispáni abban is, mint másokéban, szabadosan inquiráljanak és exequáljanak is [...].” Uo. 321-322. Kérdés, hogy Kun magatartásában mennyire játszott szerepet szatmári főkapitánysága, illetve 1626-ban szerzett bárói címe. Magyar Királyi Könyvek VII. 518-520. (http://mnl.gov.hu/ adatbazisok)

35 Uo. 432.

36 Uo. 402.

37 EOE X. 222.

38 EOE XI. 74-75. 
országgyülésen a rendek célkeresztjébe. Összesítve tehát Déva, Fogaras, Görgény, Gyalu, (esetleg Kővár) és Vécs váruradalmakkal, Máramaros, Szörény, Zaránd vármegyékkel és itt birtokos magánszemélyekkel, illetve két elkülönülő esettel, Újtordával és a Szunyogh Gáspár birtokolta kövesdi uradalommal kapcsolatban merült fel a szabad uraság. (A Kornis Boldizsáré nem került az országgyúlés napirendjére.) A korábban említett sajátos jelenség futó áttekintésre is világossá válik: csaknem kizárólag olyan területekről van szó, amelyek: 1. királyi (esetlegesen a vazallus román vajdák által birtokolt) vagy püspöki birtokok voltak a Mohács, illetve az 1541 előtti időszakban és azt követően is; 2. az ország olyan peremvidékei vagy speciális feladatot ellátó lakosságú területei, amelyeknek ebből kifolyólag sajátos helyzetük volt (Máramaros, Szörény, és ide illeszthető mint kiváltságolt katonanépesség elvileg Ủjtorda is). Tálcán kínálta magát tehát az a következtetés, amelyet magam is korábbi kutatásaim alkalmával levontam, hogy a liber baronatusi jog ezekben, akárcsak a jus regium, vagy eleve benne lappangott, vagy a sajátos fejlődésből fakadt, és az esetleges fejedelmi adomány ezt csak szentesítette. A válasz azonban korántsem ilyen egyszerű. Egyrészt azért, mert ha valóban csak ebből eredt volna, akkor folyamatosan, azaz minden magánbirtokos esetében így kellett volna viselkedniük, ez pedig egyáltalán nem így történt. Erre részben magyarázatul szolgálhat a fejedelmi/uralkodói adomány esetleges hiánya, ám egyelőre mindössze hétről (Nádasdy és társai, Bekes Gáspár, Báthory Boldizsár, Bocskai István és Miklós, Sennyei Pongrác, Kornis Boldizsár) van tudomásunk, az esetek pedig, mint látható, ennél számosabbak. Felmerült az a gondolat is (Schiller véleményét követve), hogy mivel mindannyian nagyságosok, egy-két kivétellel országos méltóságok, főtisztségek viselői, esetlegesen ezzel jár, járhatott együtt a szabad uraság, és ezt beleértik a magnificusi címbe, jogállásba. Mivel nincs nyoma annak, hogy a kortárs magnificusok hasonló előjogokkal éltek volna, vagy egyáltalán ilyeneket vindikáltak volna, ezt a magyarázatot el kellett vetni.

Mi szükséges tehát ahhoz, a fejedelmi kegyen túl, hogy az illető terület az adott pillanatban, adott magánszemély birtoklása idején ezzel az immunitással rendelkezzék, szükséges-e egyáltalán bármi más? Mi a magyarázata az olyan személyek, területek szabad úrként, illetve szabad uraságként említésének, amelyek nem rendelkeztek ilyen jogokat biztosító kiváltságlevéllel, és sohasem voltak fiscalis birtokok? Minden egyes eset alapos vizsgálata nyomán körvonalazódott annak a lehetősége és egyben szükségessége is, hogy a liber baronatus különböző típusait meghatározzuk. Az első a teljes jogú szabad uraság, azaz a jogállási, joghatósági, bíráskodási, adóügyi immunitások egészét felölelő. Itt két vonatkozásban pontosítani kell: Sennyei adománylevelének tanúsága szerint a bíráskodási joghatóság saját jobbágyain kívül kiterjedt az adott területen lakókra (,super quibusvis delictis et excessibus colonorum suorum ac aliorum ibidem residentium" ${ }^{39}$ ), a gonosztevők üldözése pedig egyaránt jelentett kiváltságot, de egyben kötelességet is (,in iisdem bonis inquisitiones peragere ac malefactores juxta demerita punire debeant et teneantur" ${ }^{30}$ ), a közrend biztosítása érdekében. Talán nem véletlen, hogy a megyei nemesség éppen erről az oldalról indított támadást. Ami pedig az adóügyet illeti, szintén a Sennyei-privilégium szerint az adott területen a dézsmaszedés jogát is magában foglalta („necnon universis decimis” ${ }^{41}$ ). A második kategóriát azok az esetek alkotják,

39 Sennyei 1t, Fasc. privilegiorum nr. VII.

40 Uo.

41 Uo. 
amelyekben a liber baronatusi jogkörök csak valamely részének, elemének birtoklásáról beszélhetünk, amelyet azonban az erdélyi társadalom szabad uraságként határozott meg.

Mivel ezek az utóbbi kategóriába tartozók könnyebben leválaszthatóak és lezárhatóak, velük kezdeném. Egyértelműen idetartozónak - mint joghatósági szabad uraságot - kell tekinteni Jósika Gábor vármegyétől való függetlenségi kísérletét, a máramarosi egyes birtokosok ellenállását a cirkálással szemben - mindkét esetben a megye határvidékjellegét is kihasználva (bár további adatokra lenne szükségünk) -, az újtordaiak „függetlenségét”, Szunyogh Gáspár és Kun László bíráskodási liber baronatusságát, hiszen mindkettő esetében csak a gonosztevők üldözéséről, megbüntetéséről van szó. Ugyanide sorolható Homonnai Bálint birtokainak adómentessége is, mint az „közteherviselési” szabad uraság példája, amelyben valószínűsíthetően a birtokok korábbi Kővárhoz tartozása játszott szerepet. Ebben az esetben is több konkrétumra lenne szükség. A csak általánosságban említett szörényi, zarándi szabad uraság kérdését egyelőre függőben kell hagynunk.

A fentiek leválasztása után a klasszikus, azaz teljes jogú szabaduraság-csoportot „visszaeső módon” csupán három terület, Fogaras (mintegy 60 falu), Görgény (1598-ban 19 egész- és 6 részbirtok, köztük egy mezőváros és egy sókamara ${ }^{42}$ ), többször Véccsel együtt (általában mintegy tíz egész- és részbirtok, Bocskai 1597-es adománylevelében összesen $21^{43}$ ) és Gyalu (1609-ben 14 egész-, illetve részbirtok és Zilah mezőváros ${ }^{44}$ ), illetve ezek öt (az 1540 -es évekbeli fogarasi társbirtokosokat, Nádasdyt, Mayláthot, Szalayt ideszámítva hat) magánbirtokosa, Bekes Gáspár, Báthory Boldizsár, Bocskai István és Miklós, valamint Sennyei Pongrác alkotja. (Dévát óvatosan számíthatjuk ide, mivel egyelőre csupán utalás szintjén tudjuk, ilyen immunitással élt.) Báthory és Bocskai Miklós esete - esetleg Bocskai István is ide sorolható - speciális, hiszen az uralkodócsalád tagjai az uralkodó életében kapták meg a fogarasi, illetve görgényi (és vécsi) uradalmat. (Az új fejedelem általi elismertetés gondjával ugyan csak utóbbinak kell szembesülnie, ám, egyedüliként, az öröklésre hivatkozhatott.) Rögtön szembeötlő: zömmel ők - tehát a két Bocskai és Sennyei (valamint Kornis) - azok, akik paradox módon, azaz de jure (az ország törvénye szerint) törvénytelenül, de facto legálisan, fejedelmi adomány alapján gyakorolták ezeket az előjogokat. Önkéntelenül adódik két kérdés, amely a korábban feltett, liber baronatushoz szükséges más tényezőkre vonatkozó kérdés megválaszolásához is hozzásegít: 1. Miért éppen ők részesültek ebben a különös kegyben? 2. Mi állhat az uralkodói döntés hátterében (miért enged át, akár inscriptio jogán is, erdélyi viszonylatban hatalmas uradalma(ka)t a kincstár érdekeit csorbítva, szabad urasággal is felruházva)? Ebben - véleményem szerint - a már többször említett idő, azaz az adott pillanatbeli politikai helyzet is jelentős szerepet játszott. Kronológiai sorrendben haladva, már Ferdinánd 1541-es adománya is sokatmondó e tekintetben. Még egyértelmúbb Bekes esete: 1567-től kezdődő fogarasi uralmát, szabad uraságát, mint már említettem, 1573-ban erősítette meg Miksa, nyilvánvalóan Báthory István akarata ellenére. A későbbi események ismeretében a cél egyértelműnek tűnik. Bocskai István szabad uraságát (igaz, csak bihari és közép-szolnoki birtokai vonatkozásában,

42 Az erdélyi káptalan jegyzőkönyvei 1222-1599. Mutatókkal és jegyzetekkel regesztákban közzéteszi Bogdándi Zsolt-Gálfi Emőke. EME, Kvár, 2006 (Erdélyi Történelmi Adatok VIII. 1). (a továbbiakban ErdKáptJkv) 960. sz.

43 JАКАв Elek: Új adatok Bocskai István életéhez. Századok XXVIII(1894). 776.

44 Sennyei lt, Fasc. privilegiorum nr. VII. 
de a biztosok jelentése alapján igencsak valószínű, hogy a ténylegesen 1598 januárjában birtokba vett ${ }^{45}$ Görgényre és Vécsre is rendelkezett hasonlóval, vagy pedig kihasználva helyzetét, kiterjesztette ezekre is) Báthory Zsigmond 1598. március 29-én kiadott oklevele biztosította. ${ }^{46}$ Közismert: a március 23-i országgyülés már elrendelte a Rudolfnak leteendő hűségesküt, április 10-én pedig Zsigmond elbúcsúzott az országtól. Augusztusi visszatérésekor visszafogadásában Bocskai kulcsszerepet játszott, ahogyan már 1594-ben is. Dévát szintén Zsigmondnak köszönhette, megint egy figyelemre méltó időpontban. Elsődleges forrással ugyan egyelőre nem rendelkezünk, ám Szamosközy szerint a nagyon megerősített Déva várát a hozzá tartozó, igen jövedelmező mezővárosokkal és falvakkal a nem annyira erôs, mint kellemes lakhelyet biztosító Sajó és Vécs kastélyaiért cserébe eszközölte ki Bocskainak a már fejedelemmé tett Báthory András bíborostól, Bocskai újabb prágai követsége idején. ${ }^{47}$ Azaz harmadik lemondását követően, 1599 első hónapjaiban. (Bethlen Farkas, Szamosközy nyomán, kis eltéréssel ugyanezt állítja. ${ }^{48}$ ) Az eddigiek alapján az sem tekinthető véletlen egybeesésnek, hogy 1600 szeptemberében Mihály vajda erdélyi lakóhelyként Fogarast, Görgényt és Vécset kérte, ${ }^{49}$ ezzel szemben Basta az ország közepén fekvő Gyalut javasolta az uralkodónak. ${ }^{50}$ Bocskai Miklós és Sennyei Pongrác esetében (ahogyan a Kornis Boldizsáréban is) Báthory Gábornak valószínúleg a megnyerés, teljes lekötelezés lehetett a célja, ami nem csak nekik, hanem az általuk képviselt politikai csoportosulásnak és II. Mátyásnak egyaránt szólt. Talán nem megalapozatlan arra következtetnünk, hogy a liber baronatust saját hatalmi támaszpontként (esetleg az arisztokrácián belüli erőviszonyok alakításának szándékával) vagy a megnyerés ideiglenes eszközeként a fejedelmi akarat hívta életre. Ahogyan, véleményem szerint, megszüntetésében is az uralkodó legalább annyira érdekelt volt vagy még inkább, mint a rendek. Úgy vélem, ezt a felszámolására tett kísérletek, intézkedések időpontjai is alátámasztják: Rudolf biztosai 1598 októberében, Zsigmond sikeres visszatérését követően próbálták, ugyan nem sok reménnyel, kirántani a talajt a fejedelem legfóbb támaszainak ítélt Bocskai és Náprágyi alól. Az országgyúlés 1607-es tiltásakor Bocskai István végrendelete értelmében Fogaras és Gyalu ugyan a kincstárra szállt, ${ }^{51}$ Görgény és Vécs azonban Bocskai Miklós, ${ }^{52}$ Déva Nyáry Pál, ${ }^{53}$ Kővár pedig elvileg Haller Gábor idősebb fiának öröksége lett volna ${ }^{54}$ (gyakorlatilag Homonnai Bálint szerezte meg). A Bocskai István végakarata ellenére fejede-

45 Iktatás: 1598. jan. 20., ErdKáptJkv 960. sz.

46 ЈАКАв: i.m. 777.

47 Szamosközy István történeti maradványai 1566-1603. II. 1598-1599. Kiadta SzILÁGyi Sándor. MTA, Bp., 1876 (Monumenta Hungariae Historica. Scriptores XXVIII). 232.

48 Bethlen Farkas: Erdély története V. (1598-1600). Ford. Kasza Péter. Enciklopédia, Bp., 2010. 97.

49 Basta György hadvezér levelezése és iratai. I. 1597-1602. Közrebocsátja Veress Endre. Magyar Tudományos Akadémia, Bp., 1909 (Monumenta Hungariae Historica. Diplomataria XXXVII). 420.

50 Uo. 421; Documente privitoare la istoria românilor. Culese de Eudoxiu Hurmuzaki. IV. 1. 1600-1649. Academia Română, Buc., 1882.147.

51 Bocskai István Testámentomi rendelése. Előszó, jegyz., szerk. Szigethy Gábor. Holnap, Bp., 2001. 21.

52 Uo. 22.

53 Uo. 24.

54 Uo. 23. 
lemmé választott Rákóczi Zsigmond nem volt érdekelt az előbbiek liber baronatusságának fenntartásában (talán az sem véletlen, Rákóczi korábbi, nagyon diplomatikus lépéseinek ismeretében, hogy az artikulusból a birtokosok neve kimaradt, azaz nem személyre szóló a támadás.) Megjegyzésre érdemes, hogy az 1630-as években szabad uraságtól megfosztottak közül Szunyogh Gáspár ugyan Bethlen bizalmas híve, kővári főkapitánya volt (1630 augusztusáig) - lehetséges, hogy az itteni, kincstári szabad uraságot terjesztette ki saját birtokaira -, de Bethlen halálát követően Brandenburgi Katalin pártjára állt, majd a gubernátor pártjától elszenvedett vereséget követően távozott Erdélyből. (Az említett kövesdi birtokot Kemény János vásárolta meg. ${ }^{55}$ ) Kun Lászlót a fejedelem magyarországi hívei között, ${ }^{56}$ Jósika Gábort pedig Esterházy Miklós környezetéhez tartozónak, a fejedelem halála után vissza-beköltözőként, a katolikus párt tagjaként sorolja fel Kemény János. ${ }^{57}$ Az örök gyanakvó Rákóczinak tehát szintén nem füződött érdeke az előjogok biztosításához. Nem lehet csupán a véletlen számlájára írni azt sem, hogy minden teljes jogú szabad uraság erőszakos véget ért, és tulajdonképpen 1609/1610-re, Bocskai Miklós és Sennyei birtokainak elkobzásával ez a formája el is tûnt az erdélyi államban.

A Rákócziak alatt az 1631-től fogarasi főkapitány, majd 1648-ban öreg Rákóczi György végakaratának megfelelően a vécsi uradalmat (visszaemlékezései szerint ugyan a família által „megmelyesztve, avagy felit, zsírját elvőve”) elnyerő ${ }^{58}$ Kemény János valamiféle, inkább informális liber baronatussága észlelhető. Ezt egyelőre csupán a teljes joghatóságú úriszék működtetése tanúsítja, a főkapitányságot a Fehér vármegyei főispánsággal párhuzamosan viselő, összefüggő uradalmakat kiépítő (pl. Csombord, Gerend) főrend hatalma nyomasztóan telepedett a vidékre. ${ }^{59}$

Összegezve: véleményem szerint az erdélyi magánszemélyek liber baronatusa nem természetes fejlődés eredménye, hanem valóban egy idegen (az ismétlődő, „minthogy nem is volt”, tiltakozások is jelzik), mesterségesen, azaz az uralkodói akarat által létrehozott intézmény. Az erdélyi rendek egy (liber) baronatust, a mindenkori uralkodóét ismerték el („egy báró van, tudniillik az vajda vagy gubernátor”, ${ }^{60}$ „elég egy fő Erdélyben, ki mindeneknek parancsoljon, nem kell több szabados úr" $\left.{ }^{61}\right)$. A klasszikus értelemben vett liber baronatusi előjogokat azaz az adott területen mindenféle más joghatóság alóli teljes mentességet, a legfőbb bíráskodási, pénzügyi attribútumokat - magánszemély csak abban az esetben élvezhette, amennyiben az alábbi feltételek teljesültek: az uralkodó akarata, kegye, emellett az uradalom korábban is fiskális vagy egyházi birtoklású volt, azaz a környezete és az ország társadalma által némiképp „megszokott” immunitással rendelkezett. Harmadsorban pedig a megadományozott az

55 Kemény János Önéletírása = Kemény János és Betblen Miklós múvei. Szöveggond., jegyz. V. Windisch Éva. Szépirodalmi, Bp., 1980. (a továbbiakban KJÖn) 108.

56 Uo. 95.

57 Uo. 110.

58 KJÖn 304.

59 Fehér vármegye tisztségviselői karának saját udvari szolgáiból való kiépítésére lásd DÁNÉ Veronka: Mezóvárosi polgárból vármegyei „elökeloo": Mészáros Péter Fehér vármegyei alispán karrierje = Arisztokrata életpályák és életviszonyok. Szerk.: PAPP Klára-Püsкi Levente. Debreceni Egyetem Történelmi Intézete, Debrecen, 2009 (Speculum Historiae Debreceniense 4). 41-47.

60 TvmJkv I. 51.

61 Uo. 
állam politikai életében döntő vagy kiemelkedő szerepet játszó, lekötelezésre érdemes személy, aki ezeket az előjogokat érvényesíteni tudta, ha csak ideiglenesen is.

Azon túl, hogy a liber baronatust természetesen a társadalmi emelkedés, a karrier fokmérójeként is tekinthetjük, bizonyos mértékben a rendeken belüli, illetve a rendek és a fejedelem közti erőviszonyok alakulását, de az erdélyi politikai élet változásait is tükrözi. Nem véletlen, hogy a Fejedelemségben kérészéletủnek bizonyult.

\section{THE LIBER BARONATUS IN THE PRINCIPALITY OF TRANSYLVANIA (1541-1658)}

\section{Keywords: liber baronatus, history of law, Principality of Transylvania}

The essay explores the development and the history of liber baronatus throughout the first century of the independent Transylvanian state. In order to rectify the errors of preceding scholarly literature and to supplement sound but partial claims, the author primarily assembled - based on the acts of Parliament and on other kinds of sources from a wide spectrum - the inventory of territories and private individuals practicing their privileges of liber baronatus (either granted by the monarch or not). By the analysis of every known case, it is apparent that this concerns domains which, already before the division of the Kingdom of Hungary into three parts, on the one hand, belonged to the monarch, the treasury or the church (Görgény, Fogaras and Gyalu); or, on the other, possessed a special borderland status (Karánsebes, Máramaros). The research has also made it clear that one must separate a full-right liber baronatus (that is, the entirety of immunities of jurisdiction, administration and taxation) from one that uses/abuses one of the immunities listed. The liber baronatus can be considered as a consequence of the actual political situation, not as a result of organic development. Thus, it is not surprising that the recipients of such privileges (considered as alien by the Transylvanian estates of the realm) or their status of liber baronatus usually came to a violent end; and when the troubled times, that is, their heyday, had ended, the liber baronatus of private individuals practically ceased in Transylvania in mid- $17^{\text {th }}$ century.

\section{LIBER BARONATUL ÎN PRINCIPATUL TRANSILVANIEI (1541-1658)}

\section{Cuvinte-cheie: liber baronat, istoria dreptului, Principatul Transilvaniei}

Studiul prezintă evoluția, istoria instituției baronatului liber (liber baronatus) în primul secol de existență a Principatului Transilvaniei. În vederea corectării erorilor întâlnite în literatura de specialitate și totodată pentru completarea constatărilor valabile, dar parțiale pe baza articolelor dietale și a numeroaselor izvoare de alt gen, autorul face un inventar al persoanelor și a teritoriilor pomenite cu acest statut. Chiar și după o analiză în treacăt devine clar, că teritoriile în caz încă înaintea destrămării Regatului Ungar erau ori domenii regale/fiscale (Gurghiu, Făgăraş) sau ecleziastice/episcopale (Gilău) ori fiind regiuni de graniță care bucuraseră de un statut special (Caransebeș, Maramureș), iar persoanele învestite cu acest privilegiu proveneau ori din familia sau rudenia apropiată a suveranului, ori jucau un rol hotărător în viața politică a statului. Analiza a scos la iveală și faptul că indispensabil trebuie făcut o diferențiere foarte clară între liber baronatul propriu-zis/clasic (deplină autoritate judiciară, administrativă și fiscală) și cea parțială (exercitarea uneia dintre aceste drepturi). Liber baronatul trebuie privit mai degrabă ca o consecință a situației politice a momentului respectiv și nu ca rezultatul unei evoluții organice, interne. $\mathrm{Ca}$ urmare, în mod deloc surprinzător majoritatea liber baronaturilor, considerate o instituție străină de stările transilvănene, au avut un sfârșit violent, iar după încetarea perioadelor de criză pe la jumătatea secolului al XVII-lea dispăruse din istoria Transilvaniei. 